\title{
Efektifitas Penyuluhan Kesehatan tentang SADARI dengan Metode \\ Diskusi Kelompok dan Metode Demonstrasi terhadap Perilaku WUS dalam Melakukan SADARI
}

\author{
${ }^{1}$ U. Masturo*, ${ }^{2}$ Kholisotin, ${ }^{3}$ Y.D Agustin, \\ ${ }^{1,2}$ Program Studi Keperawatan, Fakultas Kesehatan, Universitas Nurul Jadid \\ ${ }^{3}$ Program Studi D-III Keperawatan, Universitas Bondowoso \\ *Email Korepondensi: ucikmast@gmail.com
}

\section{Kata kunci :}

Penyuluhan,

Diskusi Kelompok,

Demonstrasi,

SADARI

Keywords :

Extension,

GroupDiscussion,

Demonstration,

SADARI

Info Artikel:

Tanggal dikirim:

13 Oktober 2019

Tanggal direvisi:

28 November 2019

Tanggal diterima :

20 Desember 2019

DOI Artikel:

10.33862/citradelima.

v3i2.86

Halaman: 141 - 154

\begin{abstract}
Abstrak
Wanita diseluruh dunia memiliki resiko menderita kanker sehingga perlu adanya deteksi dini SADARI. Tujuan penelitian untuk mengetahui efektifitas penyuluhan kesehatan tentang SADARI dengan metode diskusi dan metode demonstrasi terhadap perilaku di Desa Ambulu Kecamatan Wringin Kabupaten Bondowoso. Desain penelitian pre-eksperimental tipe two-group pretest-posttest design dengan jumlah sampel sebanyak 84 orang dengan teknik Purposive Sampling. Kemudian dianalisis dengan uji statistik Mann Whitney dan wilcoxon dengan tingkat kemaknaan $\alpha \leq 0.05$ untuk mengetahui perbandingan antara dua kelompok yang berbeda. Hasil penelitian menunjukkan ada perbedaan penyuluhan kesehatan dengan metode diskusi dan demonstrasi terhadap perilaku. Kesimpulan, metode demonstrasi lebih efektif dari pada metode diskusi kelompok dalam meningkatkan perilaku.
\end{abstract}

\section{Effectiveness of Health Education about SADARI with Methods Group Discussion and Demonstration Methods for WUS Behavior in Conducting SADARI}

\section{Abstract}

Women all over the world are at risk of developing cancer, so early detection is necessary SADARI. The aim of the study was to determine the effectiveness of health education about BSE using discussion methods and demonstration methods on behavior in Ambulu Village, Wringin District, Bondowoso District. The research design used the preeksperimental two-group pretest-posttest design with a total sample of 84 people with purposive sampling technique. Then analyzed by Mann Whitney and Wilcoxon statistical tests with a significance level of $\alpha \leq 0.05$ to determine the comparison between two different groups. The results showed that there were differences in health education with methods of discussion and demonstration of behavior. The conclusion that the demonstration method is more effective than the group discussion method in improving behavior.
\end{abstract}

\section{PENDAHULUAN}

Kanker payudara adalah akumulasi dari sel-sel abnormal di dalam payudara yang pertumbuhannya tidak terkontrol dan berlipat ganda. Ini akumulasi sel akhirnya membentuk benjolan di payudara dan ketika tidak diangkat atau dikendalikan sel-sel ini akan menyebar ke jaringan lain yang disebut metastasis dan dapat menyebabkan kematian.(Marhaeni, 2017)
Ancaman kanker di dunia semakin meningkat seiring dengan perubahan pola hidup masyarakat. Menurut Organisasi Penanggulangan Kanker Dunia dan Badan Kesehatan Dunia, diperkirakan terjadi peningkatan kejadian kanker di dunia 300 persen pada tahun 2030 dan mayoritas terjadi di negara-negara berkembang termasuk Indonesia.(RI, 2016) 
Berdasarkan Riset Kesehatan Dasar (2017) prevalensi tumor atau kanker di Indonesia adalah 1,4 per 1000 penduduk, atau sekitar 347.000 orang. Kanker tertinggi di Indonesia pada perempuan adalah kanker payudara dan kanker leher rahim. Insiden kanker payudara masih menempati urutan pertama kasus baru dan kematian akibat kanker yaitu sebesar $43,3 \%$ dan $12,9 \%$ pada penduduk perempuan di dunia.(Damayanti, 2017)

Di Jawa Timur sendiri penderita kanker payudara tercatat menduduki peringkat pertama. Didapatkan data peningkatan pada jumlah penderita kanker payudara setiap tahunnya. Kanker payudara terjadi karena terganggunya sistem pertumbuhan sel di dalam jaringan payudara. Wanita dapat bertahan hidup bertahun-tahun setelah didiagnosis kanker payudara, namun penyakit ini tidak dapat disembuhkan jika ditemukan pada stadium lanjut.(Nurfadilah, Puput, Puji Astuti, 2016)

Untuk Kabupaten Bondowoso angka kejadian kanker payudara pada tahun 2018 mencapai 201 orang. Dengan kasus lama laki-laki 9 orang, perempuan 66 orang dan kasus baru pada laki-laki 25 orang dan perempuan 101 orang.(Kesehatan, 2018)

Pemeriksaan payudara sendiri (SADARI) merupakan salah satu cara untuk mencegah secara dini kejadian kanker payudara pada remaja yang memiliki faktor resiko seperti faktor usia, faktor genetik, faktor sistem reproduksi, faktor obesitas, dan pada remaja putri yang mengkonsumsi alkohol dengan gaya hidup yang tidak sehat.(Nurfadilah, Puput, Puji Astuti, 2016)

Salah satu upaya untuk meningkatkan melakukan SADARI adalah melalui penyuluhan dengan pelatihan SADARI. Penyuluhan kesehatan adalah suatu kegiatan promosi kesehatan berupa pemberian informasi atau pesan kesehatan untuk memberikan atau meningkatkan pengetahuan dan sikap tentang kesehatan agar memudahkan dalam terjadinya perilaku sehat.(Notoatmodjo, 2014)

Untuk para wanita usia subur (WUS) yang memiliki tingkat pengetahuan dan pemahaman rendah tentang kanker payudara dan cara deteksinya maka perlu diberikan informasi dengan cara memberikan penyuluhan kesehatan tentang SADARI.(Damayanti, 2017)
Menurut penelitian yang dilakukan Dewi Puji Lestari mengungkapkan bahwa terdapat peningkatan pengetahuan, sikap dan praktik pada kelompok perlakuan setelah penyuluhan SADARI, ada perbedaan praktik kelompok perlakuan. Sedangkan pada kelompok kontrol tidak ada perbedaan praktik.(Lestari, 2016)

Hal serupa juga dikemukakan oleh Arif Yulinda, bahwa terdapat perbedaan yang signifikan antara pengetahuan dan sikap sebelum dan sesudah diberikan penyuluhan kesehatan pada remaja putri tersebut. Berdasarkan hasil penelitian diatas metode dan media yang digunakan dalam penyampaian penyuluhan kesehatan juga memberikan kontribusi dalam berhasilnya penangkapan pesan oleh remaja putri. Metode yang digunakan dalam penyuluhan adalah metode ceramah dan media audio visual berupa video.(Yulinda, 2018)

Penyuluhan kesehatan yang diberikan bertujuan untuk memberikan pengetahuan kesehatan tentang SADARI kepada WUS sehingga terjadi perubahan perilaku WUS dalam kehidupan seharihari. Karena menurut Notoatmodjo pengetahuan merupakan domain terpenting bagi terbentuknya perilaku seseorang. Pengetahuan diperlukan sebagai dorongan psikis dalam menumbuhkan sikap dan perilaku setiap hari, sehingga dapat dikatakan bahwa pengetahuan merupakan stimulasi terhadap perubahan tindakan seseorang.(Kholid, 2014)

Ada beberapa metode yang dapat digunakan dalam melakukan pendidikan kesehatan antara lain metode ceramah, diskusi kelompok, curah pendapat, panel, bermain peran, demonstrasi, simposium, dan seminar. Dimana masing-masing metode mempunyai kelebihan dan kekurangan.(Nursalam, 2017)

Alternatif metode yang dapat dipergunakan pada pendidikan kesehatan khususnya kesehatan reproduksi tentang kanker payudara adalah menggunakan metode diskusi. Metode diskusi, selain sederhana juga efektif dalam upaya penyampaian informasi secara cepat kepada kelompok sasaran. (Nursalam, 2017)

Sedangkan untuk pendidikan kesehatan tentang praktik SADARI adalah menggunakan metode demonstrasi. Metode demonstrasi lebih mudah untuk menunjukkan pengertian, ide, dan prosedur tentang suatu hal yang pernah dipersiapkan dengan teliti untuk

http://jurnalilmiah.stikescitradelima.ac.id/index.php/JI Vol.3,No.2, Januari 2020 
memperlihatkan bagaimana cara melaksanakan suatu tindakan adegan dengan menggunakan alat peraga.(Nursalam, 2017)

Menurut penelitian yang dilakukan Nurul Aeni mengungkapkan bahwa pengetahuan remaja sebelum diberikan intervensi dan setelah diberikan intervensi berupa video dan demonstrasi pengetahuan remaja mengalami peningkatan menjadi lebih baik.(Aeni, 2018)

Sedangkan untuk pendidikan kesehatan tentang praktik SADARI adalah menggunakan metode demonstrasi. Metode demonstrasi lebih mudah untuk menunjukkan pengertian, ide, dan prosedur tentang suatu hal yang pernah dipersiapkan dengan teliti untuk memperlihatkan bagaimana cara melaksanakan suatu tindakan adegan dengan menggunakan alat peraga.(Nursalam, 2017)

Hal serupa juga dikemukakan oleh Dahlina Gusti, bahwa terdapat terdapat pengaruh penyuluhan memakai metode demonstrasi terhadap peningkatan pengetahuan dan sikap remaja putri tentang pemeriksaan payudara sendiri. Berdasarkan hasil penelitian didapatkan hasil bahwa rata-rata sikap responden sebelum penyuluhan adalah 14.20. Ratarata sikap responden setelah penyuluhan adalah 18.43. nilai mean perbedaan atau selisih antara nilai sikap sebelum dilakukan penyuluhan dan setelah penyuluhan adalah 4.233. Hasil uji statistik didapatkan nilai $P$ value 0.000 maka disimpulkan ada pengaruh promosi kesehatan memakai metode penyuluhan dengan tekhnik demonstrasi terhadap sikap siswi.(Gusti, 2018)

Penelusuran oleh peneliti di Puskesmas Wringin total ada 5 kasus sedangkan di desa Ambulu ditemukan 2 orang yang terdeteksi menderita kanker payudara dan keduanya meninggal dunia meskipun sudah melakukan berbagai macam pengobatan. Penderita merupakan wanita usia subur yang sebelumnya memang jarang memeriksakan diri ke fasilitas pelayanan kesehatan sehingga penyakit yang diderita tidak bisa terdeteksi secara dini.

\section{METODE}

Desain penelitian yang digunakan dalam penelitian ini merupakan pre-eksperimental tipe twogroup pretest-posttest design yang terdiri dari 2 kelompok yang masing-masing kelompok diberikan intervensi yang berbeda. Kelompok pertama diberikan intervensi metode diskusi kelompok dan kelompok kedua diberikan intervensi metode demonstrasi dengan cara dilakukan pengukuran sebelum dan sesudah intervensi. Rancangan ini tidak menggunakan kelompok kontrol, tetapi dilakukan observasi pertama (pretest) yang memungkinkan peneliti untuk menguji perubahan-perubahan yang terjadi setelah adanya perlakuan (posttest). (Nursalam, 2017)

Analisis data yang digunakan dalam penelitian ini adalah analisis univariat, analisis bivariat dengan uji statistik Mann Whitney dan wilcoxon.

\section{HASIL PENELITIAN}

\section{Karakteristik Responden}

Tabel 1 Distribusi Karakteristik Responden

\begin{tabular}{|c|c|c|c|c|c|}
\hline \multirow{2}{*}{\multicolumn{2}{|c|}{ Karakteristik }} & \multicolumn{2}{|c|}{ Diskusi } & \multicolumn{2}{|c|}{ Demonstrasi } \\
\hline & & $\mathbf{f}$ & $\%$ & $\mathbf{f}$ & $\%$ \\
\hline \multirow[t]{3}{*}{ Usia } & $<20$ tahun & 1 & 2,4 & 1 & 2,4 \\
\hline & $20-30$ tahun & 14 & 33.3 & 22 & 52,4 \\
\hline & $>30$ tahun & 27 & 64,3 & 19 & 45,2 \\
\hline \multicolumn{2}{|c|}{ Total } & 42 & 100 & 42 & 100 \\
\hline \multirow[t]{3}{*}{ Pendidikan } & $\begin{array}{l}\mathrm{SD} / \mathrm{SMP} \\
\text { sederajat }\end{array}$ & 29 & 69,0 & 30 & 71,4 \\
\hline & $\begin{array}{l}\text { SMA/sedera } \\
\text { jat }\end{array}$ & 11 & 26,2 & 12 & 28.6 \\
\hline & Diploma/PT & 2 & 4,8 & 0 & 0.0 \\
\hline \multicolumn{2}{|c|}{ Total } & 42 & 100 & 42 & 100 \\
\hline \multirow[t]{3}{*}{ Pekerjaan } & Wiraswasta & 28 & 55,7 & 27 & 64,3 \\
\hline & $\begin{array}{l}\text { Ibu Rumah } \\
\text { Tangga }\end{array}$ & 11 & 26,2 & 14 & 33,3 \\
\hline & Pegawai & 3 & 7,1 & 1 & 2,4 \\
\hline \multicolumn{2}{|c|}{ Total } & 42 & 100 & 42 & 100 \\
\hline \multirow{4}{*}{$\begin{array}{c}\text { Jumlah } \\
\text { anak }\end{array}$} & $<3$ & 4 & 9,5 & 10 & 23,8 \\
\hline & $3-5$ & 36 & 85,7 & 32 & 76,2 \\
\hline & $>5$ & 2 & 4,8 & 0 & 0.0 \\
\hline & otal & 42 & 100 & 42 & 100 \\
\hline
\end{tabular}

Pada tabel 1 diperoleh usia responden dari kelompok diskusi paling banyak berusia > 30 tahun sebanyak 27 responden $(64,3 \%)$ dan dari kelompok demonstrasi paling banyak berusia 20-30 tahun sebanyak 22 responden $(52,4 \%)$. Pendidikan pada kelompok diskusi paling banyak berpendidikan SD/SMP sederajat sebanyak 29 responden (69,0\%) dan dari kelompok demonstrasi paling banyak berpendidikan SD/SMP sederajat sebanyak 30 responden (71,4 \%). Pekerjaan responden dari kelompok diskusi paling banyak wiraswasta sebanyak 28 responden $(55,7 \%)$ dan dari kelompok demonstrasi pekerjaan paling banyak wiraswasta sebesar 27 responden $(64,3 \%)$. Jumlah anak responden dari kelompok diskusi paling banyak 3 - 5 anak sebanyak

http://jurnalilmiah.stikescitradelima.ac.id/index.php/JI Vol.3,No.2, Januari 2020 
36 responden $(85,7 \%)$ dan dari kelompok demonstrasi jumlah anak paling banyak 3 - 5 anak sebanyak 32 responden $(76,2 \%)$.

2. Tingkat Pengetahuan WUS sebelum dan sesudah dilakukan penyuluhan kesehatan tentang SADARI dengan metode diskusi kelompok

Tabel 2 Distribusi Frekuensi Tingkat Pengetahuan WUS Sebelum dan Sesudah dilaksanakan Penyuluhan Kesehatan dengan metode diskusi kelompok.

\begin{tabular}{clcccc}
\hline \multirow{2}{*}{ Aspek } & \multirow{2}{*}{ Kategori } & \multicolumn{2}{c}{ Sebelum } & \multicolumn{2}{c}{ Sesudah } \\
\cline { 2 - 6 } & & f & \% & f & \% \\
\hline \multirow{2}{*}{ Pengetahuan } & Kurang & 10 & 23,8 & 4 & 9,5 \\
\cline { 2 - 6 } & Cukup & 18 & 42,9 & 6 & 14,3 \\
\cline { 2 - 6 } & Baik & 14 & 33,3 & 32 & 76,2 \\
\hline \multicolumn{2}{c}{ Total } & $\mathbf{4 2}$ & $\mathbf{1 0 0 , 0}$ & $\mathbf{4 2}$ & $\mathbf{1 0 0 , 0}$ \\
\hline
\end{tabular}

Pada tabel 2 diketahui bahwa, tingkat pengetahuan responden sebelum dilaksanakan penyuluhan kesehatan tentang SADARI paling banyak berkategori cukup dengan jumlah 18 responden (42,9\%). Sesudah dilaksanakan penyuluhan kesehatan tentang SADARI didapatkan hasil tingkat pengetahuan responden paling banyak berkategori baik dengan jumlah 32 responden $(76,2 \%)$.

3. Sikap WUS sebelum dan sesudah dilakukan penyuluhan kesehatan tentang SADARI dengan metode diskusi kelompok

Tabel 3. Distribusi Frekuensi Sikap WUS Sebelum dan Sesudah dilaksanakan Penyuluhan Kesehatan dengan metode diskusi kelompok

\begin{tabular}{cccccc}
\hline \multirow{2}{*}{ Aspek } & \multirow{2}{*}{ Kategori } & \multicolumn{2}{c}{ Sebelum } & \multicolumn{2}{c}{ Sesudah } \\
\cline { 3 - 6 } & & f & \% & f & \% \\
\hline \multirow{2}{*}{ Sikap } & Negatif & 13 & 31,0 & 0 & 0,0 \\
\cline { 2 - 6 } & Positif & 29 & 69,0 & 42 & 100,0 \\
\hline \multicolumn{2}{c}{ Total } & $\mathbf{4 2}$ & $\mathbf{1 0 0 , 0}$ & $\mathbf{4 2}$ & $\mathbf{1 0 0 , 0}$ \\
\hline
\end{tabular}

Pada tabel 3 diketahui bahwa sikap responden sebelum dilaksanakan penyuluhan kesehatan tentang SADARI paling banyak berkategori positif dengan jumlah 29 responden $(69,0 \%)$. Sesudah dilaksanakan penyuluhan kesehatan tentang SADARI didapatkan peningkatan hasil sikap responden yaitu semuanya berada dikategori positif dengan jumlah 42 responden $(100,0 \%)$.

\section{Tindakan WUS sebelum dan sesudah dilakukan penyuluhan kesehatan tentang SADARI dengan metode diskusi kelompok}

Tabel 4 Distribusi Frekuensi Tindakan WUS

Sebelum dan Sesudah dilaksanakan Penyuluhan

Kesehatan dengan metode diskusi kelompok

\begin{tabular}{clcccc}
\hline \multirow{2}{*}{ Aspek } & \multirow{2}{*}{ Kategori } & \multicolumn{2}{c}{ Sebelum } & \multicolumn{2}{c}{ Sesudah } \\
\cline { 3 - 6 } Tindakan & Tidak & f & \% & f & \% \\
\cline { 2 - 6 } & Terampil & 21 & 50,0 & 12 & 28,6 \\
\cline { 2 - 6 } & Terampil & 21 & 50,0 & 30 & 71,4 \\
\hline Total & $\mathbf{4 2}$ & $\mathbf{1 0 0 , 0}$ & $\mathbf{4 2}$ & $\mathbf{1 0 0 , 0}$ \\
\hline
\end{tabular}

Pada tabel 4 diketahui bahwa tindakan responden sebelum dilaksanakan penyuluhan kesehatan tentang SADARI berkategori tidak terampil maupun terampil dengan jumlah 21 responden $(50,0 \%)$. Sesudah dilaksanakan penyuluhan kesehatan tentang SADARI didapatkan peningkatan hasil tindakan responden dikategori terampil menjadi 30 responden $(71,4 \%)$.

5. Tingkat Pengetahuan WUS sebelum dan sesudah dilakukan penyuluhan kesehatan tentang SADARI dengan metode demonstrasi

Tabel 5 Distribusi Frekuensi Tingkat Pengetahuan WUS Sebelum dan Sesudah dilaksanakan Penyuluhan Kesehatan dengan metode demonstrasi

\begin{tabular}{clcccc}
\hline \multirow{2}{*}{ Aspek } & \multirow{2}{*}{ Kategori } & \multicolumn{2}{c}{ Sebelum } & \multicolumn{2}{c}{ Sesudah } \\
\cline { 2 - 6 } & & $\mathbf{f}$ & $\mathbf{\%}$ & $\mathbf{f}$ & $\mathbf{\%}$ \\
\hline Pengetahuan & Kurang & 6 & 14,3 & 1 & 2,4 \\
\cline { 2 - 6 } & Cukup & 24 & 57,1 & 3 & 7,1 \\
\cline { 2 - 6 } & Baik & 12 & 28,6 & 38 & 90,5 \\
\hline \multicolumn{2}{c}{ Total } & $\mathbf{4 2}$ & $\mathbf{1 0 0 , 0}$ & $\mathbf{4 2}$ & $\mathbf{1 0 0 , 0}$ \\
\hline
\end{tabular}

Pada tabel 5 diketahui bahwa, tingkat pengetahuan responden sebelum dilaksanakan penyuluhan kesehatan tentang SADARI paling banyak berkategori cukup dengan jumlah 24 responden $(57,1 \%)$. Sesudah dilaksanakan penyuluhan kesehatan tentang SADARI didapatkan hasil tingkat pengetahuan responden paling banyak berkategori baik dengan jumlah 38 responden $(90,5 \%)$.

6. Sikap WUS sebelum dan sesudah dilakukan penyuluhan kesehatan tentang SADARI dengan metode demonstrasi

http://jurnalilmiah.stikescitradelima.ac.id/index.php/JI Vol.3,No.2, Januari 2020 
Tabel 6 Distribusi Frekuensi Sikap WUS Sebelum dan Sesudah dilaksanakan Penyuluhan Kesehatan dengan metode demonstrasi

\begin{tabular}{cccccc}
\hline \multirow{2}{*}{ Aspek } & \multirow{2}{*}{ Kategori } & \multicolumn{2}{c}{ Sebelum } & \multicolumn{2}{c}{ Sesudah } \\
\cline { 3 - 6 } & & f & \% & f & \% \\
\hline \multirow{2}{*}{ Sikap } & Negatif & 8 & 19,0 & 1 & 2,4 \\
\cline { 2 - 6 } & Positif & 34 & 81,0 & 41 & 97,6 \\
\hline \multicolumn{2}{c}{ Total } & $\mathbf{4 2}$ & $\mathbf{1 0 0 , 0}$ & $\mathbf{4 2}$ & $\mathbf{1 0 0 , 0}$ \\
\hline
\end{tabular}

Pada tabel 6 diketahui bahwa, sikap responden sebelum dilaksanakan penyuluhan kesehatan tentang SADARI paling banyak berkategori positif dengan jumlah 34 responden $(81,0 \%)$. Sesudah dilaksanakan penyuluhan kesehatan tentang SADARI didapatkan peningkatan hasil sikap responden yaitu semuanya berada dikategori positif dengan jumlah 41 responden $(97,6 \%)$.

\section{Tindakan WUS sebelum dan sesudah dilakukan} penyuluhan kesehatan tentang SADARI dengan metode demonstrasi

Tabel 7 Distribusi Frekuensi Tindakan WUS Sebelum dan Sesudah dilaksanakan Penyuluhan Kesehatan dengan metode demonstrasi

\begin{tabular}{cccccc}
\hline \multirow{2}{*}{ Aspek } & \multirow{2}{*}{ Kategori } & \multicolumn{2}{c}{ Sebelum } & \multicolumn{2}{c}{ Sesudah } \\
\cline { 3 - 6 } & f & $\mathbf{\%}$ & $\mathbf{f}$ & $\mathbf{\%}$ \\
\hline Tindakan & Tidak Terampil & 23 & 54,8 & 7 & 16,7 \\
\hline & Terampil & 19 & 45,2 & 35 & 83,3 \\
\hline Total & $\mathbf{4 2}$ & $\mathbf{1 0 0 , 0}$ & $\mathbf{4 2}$ & $\mathbf{1 0 0 , 0}$ \\
\hline
\end{tabular}

Pada tabel 7 diketahui bahwa tindakan responden sebelum dilaksanakan penyuluhan kesehatan tentang SADARI berkategori tidak terampil dengan jumlah 23 responden (54,8\%). Sesudah dilaksanakan penyuluhan kesehatan tentang SADARI didapatkan peningkatan hasil tindakan responden berkategori terampil menjadi 35 responden $(83,3 \%)$.

8. Tingkat Pengetahuan WUS sebelum dan sesudah dilakukan penyuluhan kesehatan tentang SADARI dengan metode diskusi kelompok dan metode demonstrasi

Tabel 8 Tingkat Pengetahuan WUS sebelum dan sesudah dilakukan penyuluhan kesehatan dengan metode diskusi kelompok dan metode demonstrasi

\begin{tabular}{lccc}
\hline \multirow{2}{*}{ Metode } & \multicolumn{2}{c}{ Rerata } & $\begin{array}{c}\text { Sig (2- } \\
\text { tailed) } \\
\text { Value }\end{array}$ \\
\cline { 2 - 4 } & Sebelum & Sesudah & 0,000 \\
\hline $\begin{array}{l}\text { Diskusi } \\
\text { Kelompok }\end{array}$ & 6,52 & 8,05 & 0,000 \\
\hline Demonstrasi & 6,67 & 8,86 & 0,000 \\
\hline
\end{tabular}

Pada tabel 8 menunjukkan bahwa rerata tingkat pengetahuan dengan metode diskusi kelompok sebelum dan sesudah diberi perlakuan mengalami peningkatan yaitu dari 6,52 menjadi 8,05. Dilihat dari uji statistik $\mathrm{p}=0,000 \quad(\mathrm{p}<0,05)$ yaitu menunjukkan bahwa ada pengaruh tingkat pengetahuan sebelum dan sesudah diberikan penyuluhan kesehatan tentang SADARI. Rerata tingkat pengetahuan dengan metode demonstrasi sebelum dan sesudah diberi perlakuan mengalami peningkatan yaitu dari 6,67 menjadi 8,86 . Dilihat dari uji statistik $\mathrm{p}=0,000 \quad(\mathrm{p}<0,05)$ yaitu menunjukkan bahwa ada pengaruh tingkat pengetahuan sebelum dan sesudah diberikan penyuluhan kesehatan tentang SADARI.

9. Sikap WUS sebelum dan sesudah dilakukan penyuluhan kesehatan tentang SADARI dengan metode diskusi kelompok dan metode demonstrasi

Tabel 9 Sikap WUS sebelum dan sesudah dilakukan penyuluhan kesehatan dengan metode diskusi kelompok dan metode demonstrasi

\begin{tabular}{lccc}
\hline \multirow{2}{*}{ Metode } & \multicolumn{2}{c}{ Rerata } & $\begin{array}{c}\text { Sig (2- } \\
\text { tailed) } \\
\text { Value }\end{array}$ \\
\cline { 2 - 4 } & Sebelum & Sesudah & 0,000 \\
\hline $\begin{array}{l}\text { Diskusi } \\
\text { Kelompok }\end{array}$ & 5,81 & 8,19 & \\
\hline Demonstrasi & 6,64 & 8.64 & 0,000 \\
\hline
\end{tabular}

Pada tabel 9 menunjukkan bahwa rerata sikap dengan metode diskusi kelompok sebelum dan sesudah diberi perlakuan mengalami peningkatan yaitu dari 5,81 menjadi 8,19. Hasil uji statistik sikap $\mathrm{p}=0,000$ $(\mathrm{p}<0,05)$ menunjukkan bahwa terdapat pengaruh sikap sebelum dan sesudah dilakukan perlakuan. Rerata sikap dengan metode demonstrasi sebelum dan sesudah diberi perlakuan mengalami peningkatan yaitu dari 6,64 menjadi 8,64. Hasil uji statistik sikap $\mathrm{p}=0,000$ $(\mathrm{p}<0,05)$ menunjukkan bahwa terdapat pengaruh sikap sebelum dan sesudah dilakukan perlakuan.

\section{Tindakan WUS sebelum dan sesudah dilakukan penyuluhan kesehatan tentang SADARI dengan metode diskusi kelompok dan metode demonstrasi}

Tabel 10 Tindakan WUS sebelum dan sesudah dilakukan penyuluhan kesehatan dengan metode diskusi kelompok dan metode demonstrasi

http://jurnalilmiah.stikescitradelima.ac.id/index.php/JI Vol.3,No.2, Januari 2020 


\begin{tabular}{|c|c|c|c|}
\hline \multirow[b]{2}{*}{ Metode } & \multicolumn{2}{|c|}{ Rerata } & \multirow{2}{*}{$\begin{array}{l}\text { Sig (2- } \\
\text { tailed) } \\
\text { Value }\end{array}$} \\
\hline & Sebelum & Sesudah & \\
\hline $\begin{array}{l}\text { Diskusi } \\
\text { Kelompok }\end{array}$ & 6,64 & 9,45 & 0,000 \\
\hline Demonstrasi & 6,43 & 11,10 & 0,000 \\
\hline
\end{tabular}

Pada tabel 10 menunjukkan bahwa rerata tindakan dengan metode diskusi kelompok sebelum dan sesudah diberi perlakuan mengalami peningkatan dilihat dari nilai rerata nya yaitu 6,64 menjadi 9,45, jika dilihat dari uji statistik mengalami perubahan tindakan yang signifikan yaitu $\mathrm{p}=0,000 \quad(\mathrm{p}<0,05)$. Tindakan dengan metode demonstrasi sebelum dan sesudah diberi perlakuan juga mengalami peningkatan dilihat dari nilai rerata nya yaitu 6,43 menjadi 11,10 , jika dilihat dari uji statistik mengalami perubahan tindakan yang signifikan yaitu $\mathrm{p}=0,000(\mathrm{p}<0,05)$.

11. Efektifitas penyuluhan kesehatan tentang SADARI dengan metode diskusi kelompok dan metode demonstrasi terhadap tingkat pengetahuan WUS dalam melakukan SADARI

Tabel 11Penyuluhan Kesehatan Dengan Metode Diskusi Kelompok Dan Metode Demonstrasi Terhadap Tingkat Pengetahuan WUS dalam melakukan SADARI.

\begin{tabular}{cccc}
\hline \multirow{2}{*}{ Aspek } & \multicolumn{2}{c}{ Rerata } & $\begin{array}{c}\text { Sig (2- } \\
\text { tailed) } \\
\text { Value }\end{array}$ \\
\cline { 2 - 4 } & $\begin{array}{c}\text { Diskusi } \\
\text { Kelompok }\end{array}$ & Demonstrasi & 0,020 \\
\hline Pengetahuan & 8,05 & 8,86 & 0,05 \\
\hline
\end{tabular}

Hasil uji statistik pada tabel 11 dengan menggunakan Mann Whitney menunjukkan bahwa rerata pengetahuan sesudah diberikan penyuluhan kesehatan melalui metode diskusi kelompok $=8,05$ dan metode demonstrasi $=8,86$ dengan nilai $\mathrm{p}=0,020$ $(\mathrm{p}<0,05)$, dengan demikian pengetahuan diterima.

12. Efektifitas penyuluhan kesehatan tentang SADARI dengan metode diskusi kelompok dan metode demonstrasi terhadap sikap WUS dalam melakukan SADARI

Tabel 12Penyuluhan Kesehatan Dengan Metode

Diskusi Kelompok Dan Metode Demonstrasi Terhadap Sikap WUS dalam melakukan SADARI

\begin{tabular}{lccc}
\hline \multirow{2}{*}{ Aspek } & \multicolumn{2}{c}{ Rerata } & $\begin{array}{c}\text { Sig (2- } \\
\text { tailed) } \\
\text { Value }\end{array}$ \\
\cline { 2 - 4 } & $\begin{array}{c}\text { Diskusi } \\
\text { Kelompok }\end{array}$ & Demonstrasi & 0,330 \\
\hline Sikap & 8.19 & 8,64 & 0,30
\end{tabular}

Hasil uji statistik pada tabel 12 dengan menggunakan Mann Whitney menunjukkan bahwa rerata sikap sesudah diberikan penyuluhan kesehatan melalui metode diskusi kelompok $=8,19$ dan metode demonstrasi $=8,64$ dengan nilai $\mathrm{p}=0,330(\mathrm{p}>0,05)$, dengan demikian sikap ditolak.

13. Efektifitas penyuluhan kesehatan tentang SADARI dengan metode diskusi kelompok dan metode demonstrasi terhadap tindakan WUS dalam melakukan SADARI

Tabel 13 Penyuluhan Kesehatan Dengan Metode

Diskusi Kelompok Dan Metode Demonstrasi Terhadap Tindakan WUS dalam melakukan SADARI

\begin{tabular}{|c|c|c|c|}
\hline \multirow[b]{2}{*}{ Aspek } & \multicolumn{2}{|c|}{ Rerata } & \multirow{2}{*}{$\begin{array}{c}\text { Sig (2- } \\
\text { tailed }) \\
\text { Value }\end{array}$} \\
\hline & $\begin{array}{c}\text { Diskusi } \\
\text { Kelompok }\end{array}$ & Demonstrasi & \\
\hline Tindakan & 9,45 & 11,10 & 0,011 \\
\hline
\end{tabular}

Hasil uji statistik pada tabel 13 dengan menggunakan Mann Whitney menunjukkan bahwa Rerata tindakan sesudah diberikan pendidikan kesehatan melalui metode diskusi kelompok $=9,45$ dan metode demonstrasi $=11,10$ dengan nilai $\mathrm{p}=0,011$ $(\mathrm{p}<0,05)$, dengan demikian tindakan diterima.

\section{PEMBAHASAN}

Sebelum penyuluhan kesehatan diberikan, WUS diberikan pretest, hal tersebut dilakukan untuk mengetahui perilaku WUS sebelum diberikan penyuluhan kesehatan. Setelah pemberian penyuluhan kesehatan, WUS kembali diberikan posttest dengan pertanyaan yang sama dengan pretest. Hal tersebut dilakukan untuk mengetahui perilaku WUS setelah pemberian penyuluhan dan sebagai indikator keberhasilan penyuluhan kesehatan.

1. Tingkat Pengetahuan WUS sebelum dan sesudah dilakukan penyuluhan kesehatan tentang SADARI dengan metode diskusi kelompok

Berdasarkan hasil penelitian pada metode diskusi kelompok dapat diketahui bahwa, tingkat pengetahuan responden sebelum dilaksanakan penyuluhan kesehatan paling banyak berkategori cukup dengan jumlah 18 responden (42,9\%). Sesudah dilaksanakan penyuluhan kesehatan didapatkan hasil tingkat pengetahuan responden paling banyak berkategori baik dengan jumlah 32 responden $(76,2 \%)$.

http://jurnalilmiah.stikescitradelima.ac.id/index.php/JI Vol.3,No.2, Januari 2020 
Hasil analisis statistik pretest dan posttest menggunakan uji wilcoxon menunjukkan hasil $\mathrm{p}=$ $0,000(\mathrm{p}<0,05)$ yang berarti ada perubahan bermakna pada tingkat pengetahuan tentang SADARI pada WUS. Penelitian dengan memberikan pendidikan kesehatan tentang SADARI melalui metode diskusi kelompok secara statistik menunjukkan ada perbedaan secara signifikan yang dapat meningkatkan tingkat pengetahuan responden.

Hasil penelitian ini sejalan dengan penelitian Arif Yulinda dan Nurul Fitriyah (2018) yang menyatakan bahwa terdapat peningkatan tingkat pengetahuan dan sikap dari remaja putri di SMK Negeri 5 Surabaya mengenai cara pencegahan kanker payudara dengan deteksi dini SADARI (Pemeriksaan Payudara Sendiri). Hal tersebut didukung dengan hasil uji statistika yang menjelaskan bahwa terdapat perbedaan yang signifikan antara pengetahuan dan sikap sebelum dan sesudah diberikan penyuluhan kesehatan pada remaja putri tersebut. Isnani Diniyati Iman (2012) dalam penelitiannya juga menyimpulkan bahwa ada pengaruh penyuluhan kesehatan terhadap pengetahuan mahasiswi Keperawatan UIN Alauddin Makassar.(Diniyati, 2012)

Penelitian dengan memberikan pendidikan kesehatan tentang SADARI pada WUS melalui metode diskusi kelompok secara statistik menunjukkan ada perbedaan secara signifikan yang dapat meningkatkan perilaku WUS, sehingga disimpulkan bahwa di Desa Ambulu Kecamatan Wringin Kabupaten Bondowoso memiliki tingkat pengetahuan baik, sikap yang positif dan tindakan yang terampil dalam melaksanakan SADARI.

Berdasarkan teori telah dijelaskan bahwa pengetahuan adalah hasil tahu dari manusia dan ini terjadi setelah orang melakukan pengindraan terhadap suatu objek tertentu melalui panca indra manusia.(Notoatmodjo, 2014) Selain itu Peningkatan sikap responden dipengaruhi oleh metode pendidikan kesehatan yang digunakan. Hal ini sesuai dengan pendapat Azwar (2008), yang menyatakan bahwa pelatihan atau pendidikan dapat meningkatkan nilai sikap.(Azwar, 2008)

Notoatmodjo (2014) menyebutkan bahwa pendidikan kesehatan termasuk juga penyuluhan akan berpengaruh terhadap keterampilan. Proses belajar yang terjadi yakni pada metode diskusi, peserta mendapat informasi melalui indera pendengaran dan penglihatan dengan menggunakan media slide/powerpoint. Saat itu informasi mulai disadari, dipersepsi dan diketahui oleh peserta (awareness). Proses yang terjadi dalam tahap ini yang pertama adalah fase perkenalan yang akan mengaktifkan kembali pengetahuan yang telah diberikan melalui metode diskusi.

Fase kedua adalah eksplorasi, dimana responden didorong untuk memahami materi secara mendalam, terlibat aktif dengan saling tukar-menukar informasi melalui interaksinya dengan facilitator maupun dengan peserta yang lain. Hal ini akan menyebubkan informasi yang didapat lebih banyak, meningkatkan pemahaman yang lebih mendalam terhadap topik, mengembangkan pemikiran kritis serta perkembangan social. Fase selanjutnya yakni penutup dimana facilitator meringkaskan poin-poin utama diskusi.

Hasil penelitian ini sejalan dengan penelitian Kholisotin (2017) yang ingin mengetahui efektivitas paket pendidikan preeklampsia pada wanita hamil yang berisiko preeklampsia yang menyimpulkan bahwa dengan meningkatnya pengetahuan ibu hamil dapat mempengaruhi sikap dan tindakannya dalam memelihara kesehatan sehingga terjadinya preeklampsia/eklampsi dapat di cegah pada kehamilannya.(Kholisotin, 2017)

Menurut peneliti bahwa semakin baik pengetahuan seseorang menjamin seseorang itu semakin tidak terkena penyakit kanker payudara, demikian pula sebaliknya semakin rendah tingkat pengetahuan seseorang maka tentu makin besar kemungkinan menderita penyakit kanker payudara sesuai dengan hasil penelitian yang mengambarkan bahwa adanya pengaruh tingkat pengetahuan sebelum dan sesudah diberikan penyuluhan kesehatan tentang SADARI.

\section{Sikap WUS sebelum dan sesudah dilakukan penyuluhan kesehatan tentang SADARI dengan metode diskusi kelompok.}

Berdasarkan hasil penelitian sikap responden sebelum dilaksanakan penyuluhan kesehatan dengan metode diskusi kelompok dalam kategori positif sebanyak 29 responden (69,0\%). Sesudah dilaksanakan penyuluhan kesehatan dengan metode diskusi kelompok didapatkan peningkatan sikap responden yaitu dalam kategori positif dengan jumlah 42 responden $(100,0 \%)$. Hasil analisis statistik pretest dan

http://jurnalilmiah.stikescitradelima.ac.id/index.php/JI Vol.3,No.2, Januari 2020 
posttest menggunakan uji wilcoxon menunjukkan hasil $\mathrm{p}=0,000 \quad(\mathrm{p}<0,05)$ yang berarti ada perubahan bermakna terhadap sikap WUS sebelum dan sesudah di berikan penyuluhan kesehatan dengan metode diskusi kelompok.

Hasil penelitian ini sejalan dengan penelitian Kholisotin (2017), Pada variabel sikap, hasil uji statistik menunjukkan bahwa terdapat pengaruh yang signifikan sikap sebelum diberikan paket edukasi preeklampsia (pretest) dan sesudah diberikan paket edukasi preeklampsia (posttest) pada ibu hamil yang beresiko mengalami preeklampsia dengan $\mathrm{P}=0,021$ ( $\mathrm{P}$ $<0,05$ ). (Kholisotin, 2017)

Berdasarkan teori telah dijelaskan bahwa pengetahuan adalah hasil tahu dari manusia dan ini terjadi setelah orang melakukan pengindraan terhadap suatu objek tertentu melalui panca indra manusia.(Notoatmodjo, 2014)

Selain itu Peningkatan sikap responden dipengaruhi oleh metode pendidkan kesehatan yang digunakan. Hal ini sesuai dengan pendapat Notoatmodjo (2014) menyebutkan bahwa pendidikan kesehatan termasuk juga penyuluhan akan berpengaruh terhadap keterampilan. Proses belajar yang terjadi yakni pada metode diskusi, peserta mendapat informasi melalui indera pendengaran dan penglihatan dengan menggunakan media slide/powerpoint. Saat itu informasi mulai disadari, dipersepsi dan diketahui oleh peserta (awareness). Proses yang terjadi dalam tahap ini yang pertama adalah fase perkenalan yang akan mengaktifkan kembali pengetahuan yang telah diberikan melalui metode diskusi. Fase kedua adalah eksplorasi, dimana responden didorong untuk memahami materi secara mendalam, terlibat aktif dengan saling tukar-menukar informasi melalui interaksinya dengan facilitator maupun dengan peserta yang lain. Hal ini akan menyebabkan informasi yang didapat lebih banyak, meningkatkan pemahaman yang lebih mendalam terhadap topik, mengembangkan pemikiran kritis serta perkembangan social. Fase selanjutnya yakni penutup dimana facilitator meringkaskan poin-poin utama diskusi.

Hasil penelitian ini tidak sesuai dengan penelitian Dwi Puji Lestari (2016) yang ingin mengetahui pengaruh dari pemberian penyuluhan kesehatan terhadap pengetahuan, sikap dan praktik SADARI santri di pondok pesantren Dawar, Kabupaten Boyolali yang menyimpulkan bahwa tidak ada perbedaan sikap pretest dan posttest kelompok perlakuan setelah penyuluhan SADARI.(Lestari, 2016)

Sikap merupakan konsep paling penting dalam psikologi sosial yang membahas unsur sikap baik sebagai individu maupun kelompok. Banyak kajian dilakukan untuk merumuskan pengertian sikap, proses terbentuknya sikap maupun perubahan. Banyak pula penelitian telah dilakukan terhadap sikap kaitannya dengan efek dan perannya dalam pembentukan karakter dan sistem hubungan antar kelompok serta pilihanpilihan yang ditentukan berdasarkan lingkungan dan pengaruhnya terhadap perubahan.(Wawan, A \& Dewi, 2011)

Reaksi seseorang dan menunjukkan kesiapan untuk bereaksi terhadap stimulus tertentu. Terbentuknya sikap dipengaruhi oleh sikap orang lain dengan ekspresinya, sering pula sikap tersebut dipengaruhi oleh pembicaraan orang lain, setelah pengenalan lebih dalam, pengetahuan yang lebih luas mungkin akan merubah sikap atau menetap dan sikap itu baru berubah setelah ada pemahaman .

Menurut peneliti pengukuran sikap dapat dilakukan langsung pada responden dan sikap tidak langsung dapat melalui pertanyaan kuesioner yang mengarah pada reaksi kepercayaan dan kecenderungan responden bertindak terhadap stimulus.

Penelitian dengan memberikan pendidikan kesehatan tentang SADARI pada WUS melalui metode diskusi kelompok secara statistik menunjukkan ada perbedaan secara signifikan yang dapat meningkatkan perilaku WUS, sehingga disimpulkan bahwa di Desa Ambulu Kecamatan Wringin Kabupaten Bondowoso memiliki tingkat pengetahuan baik, sikap yang positif dan tindakan yang terampil dalam melaksanakan SADARI.

\section{Tindakan WUS sebelum dan sesudah dilakukan penyuluhan kesehatan tentang SADARI dengan metode diskusi kelompok}

Berdasarkan hasil penelitian pada metode diskusi kelompok diketahui bahwa, tindakan responden sebelum dilaksanakan penyuluhan kesehatan berkategori tidak terampil maupun terampil dengan jumlah 21 responden $(50,0 \%)$. Sesudah dilaksanakan penyuluhan kesehatan didapatkan peningkatan hasil tindakan responden dikategori terampil menjadi 30 responden $(71,4 \%)$. Hasil analisis statistik pretest dan

http://jurnalilmiah.stikescitradelima.ac.id/index.php/JI Vol.3,No.2, Januari 2020 
posttest menggunakan uji wilcoxon menunjukkan hasil $\mathrm{p}=0,000 \quad(\mathrm{p}<0,05)$ yang berarti ada perubahan bermakna pada tindakan tentang SADARI pada WUS.

Hasil penelitian ini sesuai dengan penelitian Arsyita Putri Rahmatika (2018) yang menyatakan bahwa metode diskusi dapat meningkatkan keterampilan pemeriksaan payudara sendiri (SADARI) pada siswi SMA N 1 Sewon. Penyebabnya adalah pada penyuluhan metode diskusi terdapat keterlibatan siswi berupa interaksi antar peserta maupun dengan facilitator, adanya asesmen dan umpan balik dan adanya kesempatan untuk memperdalam materi dikarenakan sebelumnya sudah ada dasar pengetahuan dari metode diskusi. (Rahmatika, 2018)

Perlakuan berupa penyuluhan pada penelitian ini adalah suatu stimulus yang diberikan dengan dua cara yang berbeda, yaitu dengan metode diskusi dan metode demonstrasi, hasil penelitian menunjukkan bahwa dengan stimulus yang berbeda akan menimbulkan hasil atau respon yang berbeda. Metode diskusi memberikan dampak pada nilai yang meningkat. Metode diskusi memanfaatkan komunikasi dua arah (two way method) serta interaksi antar individu untuk mencapai pemahaman yang lebih mendalam terhadap suatu materi (Notoatmodjo, 2014). Metode ceramah wajar dilakukan bila ingin mengajarkan topik baru, individu harus memiliki pengetahuan yang mendalam sebelum memulai diskusi. Tidak ada seorang pun yang bisa membahas atau mendiskusikan suatu topik jika tidak tahu apa pun tentang topik tersebut.

Menurut peneliti yaitu dalam diskusi kelompok ada hubungan yang kuat antara pengetahuan dengan praktek sehari-hari, yang biasanya tidak terdapat dalam metode lain seperti ceramah atau media massa, bahasa yang digunakan dalam diskusi lebih akrab bagi peserta, sehingga memungkinkan peserta tidak malu untuk berbicara, peserta dapat memberikan pertanyaan, menyampaikan gagasan atau memperbaiki pernyataan yang pernah diungkapkannya terdahulu, peserta diskusi berkesempatan untuk menemukan aspek masalah yang tidak diketahuinya.

Penelitian dengan memberikan pendidikan kesehatan tentang SADARI pada WUS melalui metode diskusi kelompok secara statistik menunjukkan ada perbedaan secara signifikan yang dapat meningkatkan perilaku WUS, sehingga disimpulkan bahwa di Desa
Ambulu Kecamatan Wringin Kabupaten Bondowoso memiliki tingkat pengetahuan baik, sikap yang positif dan tindakan yang terampil dalam melaksanakan SADARI.

\section{Tingkat Pengetahuan WUS sebelum dan sesudah dilakukan penyuluhan kesehatan tentang SADARI dengan metode demonstrasi}

Berdasarkan hasil penelitian pada metode demonstrasi diketahui bahwa tingkat pengetahuan responden sebelum dilaksanakan penyuluhan kesehatan paling banyak berkategori cukup dengan jumlah 24 responden $(57,1 \%)$. Sesudah dilaksanakan penyuluhan kesehatan didapatkan hasil tingkat pengetahuan responden berkategori baik dengan jumlah 38 responden $(90,5 \%)$. Hasil analisis statistik pretest dan posttest menggunakan uji wilcoxon menunjukkan hasil $\mathrm{p}=0,000(\mathrm{p}<0,05)$ yang berarti ada perubahan bermakna pada tingkat pengetahuan tentang SADARI pada WUS. Penelitian dengan memberikan pendidikan kesehatan tentang SADARI melalui metode demonstrasi secara statistik menunjukkan ada perbedaan secara signifikan yang dapat meningkatkan tingkat pengetahuan responden.

Hasil penelitian ini sejalan dengan penelitian Dahlina Gusti (2018) yang menyatakan bahwa terdapat pengaruh penyuluhan memakai metode demonstrasi terhadap peningkatan pengetahuan dan sikap remaja putri tentang pemeriksaan payudara sendiri. Hal tersebut didukung dengan hasil uji statistika yang menjelaskan bahwa terdapat perbedaan yang signifikan antara pengetahuan dan sikap sebelum dan sesudah diberikan penyuluhan kesehatan.(Gusti, 2018)

Proses yang terjadi dalam tahap ini yang pertama adalah fase perkenalan yang akan mengaktifkan kembali pengetahuan yang telah diberikan melalui metode demonstrasi. Fase kedua adalah eksplorasi, dimana responden didorong untuk memahami materi secara mendalam, terlibat aktif dengan saling tukar-menukar informasi melalui interaksinya dengan facilitator maupun dengan peserta yang lain. Hal ini akan menyebubkan informasi yang didapat lebih banyak, meningkatkan pemahaman yang lebih mendalam terhadap topik, mengembangkan pemikiran kritis serta perkembangan social. Fase selanjutnya yakni penutup dimana facilitator meringkaskan poin-poin utama diskusi.

http://jurnalilmiah.stikescitradelima.ac.id/index.php/JI Vol.3,No.2, Januari 2020 
Menurut peneliti, peningkatan pengetahuan WUS yang mendapat penyuluhan kesehatan tentang SADARI disebabkan karena dipraktekkan cara melakukannya sehingga WUS dapat menggunakan indra pendengaran dan penglihatan lebih maksimal dibanding dengan metode diskusi yang hanya berfokus pada indra pendengaran.

Penelitian dengan memberikan pendidikan kesehatan tentang SADARI pada WUS melalui metode demonstrasi secara statistik menunjukkan ada perbedaan secara signifikan yang dapat meningkatkan perilaku WUS, sehingga disimpulkan bahwa di Desa Ambulu Kecamatan Wringin Kabupaten Bondowoso memiliki tingkat pengetahuan baik, sikap yang positif dan tindakan yang terampil dalam melaksanakan SADARI.

\section{Sikap WUS sebelum dan sesudah dilakukan penyuluhan kesehatan tentang SADARI dengan metode demonstrasi}

Berdasarkan hasil penelitian pada metode demonstrasi diketahui bahwa, sikap responden sebelum dilaksanakan penyuluhan kesehatan berkategori positif dengan jumlah 34 responden (81,0\%). Sesudah dilaksanakan penyuluhan kesehatan didapatkan peningkatan hasil sikap responden yaitu semuanya berkategori baik dengan jumlah 41 responden $(97,6 \%)$. Hasil analisis statistik pretest dan posttest menggunakan uji wilcoxon menunjukkan hasil $\mathrm{p}=$ $0,000(\mathrm{p}<0,05)$ yang berarti ada perubahan bermakna pada sikap tentang SADARI pada WUS. Penelitian dengan memberikan pendidikan kesehatan tentang SADARI melalui metode demonstrasi secara statistik menunjukkan ada perbedaan secara signifikan yang dapat meningkatkan sikap responden.

Hasil penelitian ini sejalan dengan penelitian Dahlina Gusti (2018) yang menyatakan bahwa terdapat pengaruh penyuluhan memakai metode demonstrasi terhadap peningkatan pengetahuan dan sikap remaja putri tentang pemeriksaan payudara sendiri. Hal tersebut didukung dengan hasil uji statistika yang menjelaskan bahwa terdapat perbedaan yang signifikan antara pengetahuan dan sikap sebelum dan sesudah diberikan penyuluhan kesehatan.(Gusti, 2018)

Penelitian dengan memberikan pendidikan kesehatan tentang SADARI pada WUS melalui metode demonstrasi secara statistik menunjukkan ada perbedaan secara signifikan yang dapat meningkatkan perilaku WUS, sehingga disimpulkan bahwa di Desa Ambulu Kecamatan Wringin Kabupaten Bondowoso memiliki tingkat pengetahuan baik, sikap yang positif dan tindakan yang terampil dalam melaksanakan SADARI.

\section{Tindakan WUS sebelum dan sesudah dilakukan penyuluhan kesehatan tentang SADARI dengan metode demonstrasi}

Berdasarkan hasil penelitian pada metode demonstrasi diketahui bahwa, tindakan responden sebelum dilaksanakan penyuluhan kesehatan berkategori tidak terampil dengan jumlah 23 responden $(54,8 \%)$. Sesudah dilaksanakan penyuluhan kesehatan didapatkan peningkatan hasil tindakan responden dikategori terampil menjadi 35 responden $(83,3 \%)$. Hasil analisis statistik pretest dan posttest menggunakan uji wilcoxon menunjukkan hasil $\mathrm{p}=$ $0,000(\mathrm{p}<0,05)$ yang berarti ada perubahan bermakna pada tindakan tentang SADARI pada WUS.

Perlakuan berupa penyuluhan pada penelitian ini adalah suatu stimulus yang diberikan dengan dua cara yang berbeda, yaitu dengan metode diskusi dan metode demonstrasi, hasil penelitian menunjukkan bahwa dengan stimulus yang berbeda akan menimbulkan hasil atau respon yang berbeda. metode demonstrasi lebih mudah untuk menunjukkan pengertian, ide, dan prosedur tentang suatu hal yang pernah dipersiapkan dengan teliti untuk memperlihatkan bagaimana cara melaksanakan suatu tindakan adegan dengan menggunakan alat peraga. Keuntungan dari metode demonstrasi yaitu dapat membuat proses pembelajaran menjadi lebih jelas dan lebih konkret, lebih mudah memahami sesuatu, lebih menarik, peserta didik dirangsang untuk mengamati, menyesuaikan teori dengan kenyataan dan dapat melakukan sendiri

Notoatmodjo mengatakan terbentuknya suatu perilaku baru, teruatama pada orang dewasa dimulai pada domain kognitif, dalam arti subjek tahu terlebih dahulu terhadap stimulus yang berupa materi atau objek diluarnya, menimbulkan respon batin dalam bentuk sikap, selanjutnya akan menimbulkan respon lebih jauh lagi berupa tindakan. Perilaku yang didasari oleh pengetahuan, kesadaran dan sikap positif akan bersifat langgeng. Ini terlihat pada hasil posttest tindakan kedua kelompok perlakuan. Selain itu, pada pelaksanaan penelitian antara pengambilan data pretest dan posttest hanya selang satu minggu. Padahal tindakan

http://jurnalilmiah.stikescitradelima.ac.id/index.php/JI Vol.3,No.2, Januari 2020 
merupakan suatu aplikasi dari pengetahuan yang lebih maksimal apabila diukur dengan jarak yang lama.

Tindakan dipengaruhi oleh pengetahuan dan sikap. Tindakan yang dilakukan oleh WUS yang mendapat penyuluhan dengan metode diskusi berbeda dengan yang mendapat penyuluhan dengan metode demostrasi Perbedaan tersebut disebabkan karena pada metode demonstrasi, WUS dapat melihat langsung cara melakukan SADARI sehingga peningkatan pengetahuan dan sikap lebih tinggi.

Hasil penelitian menunjukkan bahwa tindakan didominasi dengan kategori terampil hal ini dapat disebabkan karena berbagai faktor yang mempengaruhi seperti pengetahuan, sikap, kepercayaan, nilai, tradisi serta hubungan sosial responden. Motivasi dapat berpengaruh terhadap keterampilan seperti yang disebabkan dalam penelitian Melina bahwa individu yang memiliki motivasi tinggi memiliki tingkat keterampilan yang lebih baik dibandingkan dengan siswa yang memiliki motivasi rendah. Fasilitas pelayanan kesehatan, serta sikap dan perilaku tenaga kesehatan dan tokoh masyarakat juga berpengaruh terhadap keterampilan pemeriksaan payudara sendiri (SADARI) (Notoatmodjo, 2014). Faktor-faktor tersebut tidak dikendalikan sehingga dapat berpengaruh terhadap keterampilan responden.(Notoatmodjo, 2014)

Menurut peneliti, peningkatan pengetahuan, sikap dan tindakan WUS yang mendapat penyuluhan kesehatan tentang SADARI disebabkan karena dipraktekkan cara melakukannya sehingga WUS dapat menggunakan indra pendengaran dan penglihatan lebih maksimal dibanding dengan metode diskusi yang hanya berfokus pada indra pendengaran.

Penelitian dengan memberikan pendidikan kesehatan tentang SADARI pada WUS melalui metode demonstrasi secara statistik menunjukkan ada perbedaan secara signifikan yang dapat meningkatkan perilaku WUS, sehingga disimpulkan bahwa di Desa Ambulu Kecamatan Wringin Kabupaten Bondowoso memiliki tingkat pengetahuan baik, sikap yang positif dan tindakan yang terampil dalam melaksanakan SADARI.

7. Efektifitas penyuluhan kesehatan tentang SADARI dengan metode diskusi kelompok dan metode demonstrasi terhadap tingkat pengetahuan WUS dalam Melakukan SADARI
Hasil uji statistik diperoleh nilai $\mathrm{p}=0,020$ $(\mathrm{p}<0,05)$, dengan demikian ada pengaruh pengetahuan WUS tentang SADARI. Dapat disimpulkan bahwa metode demonstrasi lebih efektif dari pada metode diskusi kelompok dalam meningkatkan pengetahuan. Hal ini sesuai dengan hasil penelitian Aprilia Hidayati (2017) yang menyatakan bahwa penyuluhan kesehatan melalui metode demonstrasi berpengaruh terhadap pengetahuan siswi tentang kanker payudara dan ketrampilan praktik SADARI.(Hidayati, 2017)

Perlakuan berupa penyuluhan pada penelitian ini adalah suatu stimulus yang diberikan dengan dua cara yang berbeda, yaitu dengan metode diskusi dan metode demonstrasi, hasil penelitian menunjukkan bahwa dengan stimulus yang berbeda akan menimbulkan hasil atau respon yang berbeda. Metode diskusi wajar dilakukan bila ingin mengajarkan topik baru. bahkan menyebutkan bahwa individu harus memiliki pengetahuan yang mendalam sebelum memulai diskusi. Tidak ada seorang pun yang bisa membahas atau mendiskusikan suatu topik jika tidak tahu apa pun tentang topik tersebut. Sedangkan metode demonstrasi lebih mudah untuk menunjukkan pengertian, ide, dan prosedur tentang suatu hal yang pernah dipersiapkan dengan teliti untuk memperlihatkan bagaimana cara melaksanakan suatu tindakan adegan dengan menggunakan alat peraga.(Mubarak, 2011)

Keuntungan dari metode demonstrasi yaitu dapat membuat proses pembelajaran menjadi lebih jelas dan lebih konkret, lebih mudah memahami sesuatu, lebih menarik, peserta didik dirangsang untuk mengamati, menyesuaikan teori dengan kenyataan dan dapat melakukan sendiri

Notoatmodjo mengatakan terbentuknya suatu perilaku baru, teruatama pada orang dewasa dimulai pada domain kognitif, dalam arti subjek tahu terlebih dahulu terhadap stimulus yang berupa materi atau objek diluarnya, menimbulkan respon batin dalam bentuk sikap, selanjutnya akan menimbulkan respon lebih jauh lagi berupa tindakan. Perilaku yang didasari oleh pengetahuan, kesadaran dan sikap positif akan bersifat langgeng. Ini terlihat pada hasil posttest tindakan kedua kelompok perlakuan. Selain itu, pada pelaksanaan penelitian antara pengambilan data pretest dan posttest hanya selang satu minggu. Padahal tindakan merupakan suatu aplikasi dari pengetahuan yang lebih maksimal apabila diukur dengan jarak yang lama.

http://jurnalilmiah.stikescitradelima.ac.id/index.php/JI Vol.3,No.2, Januari 2020 
Menurut peneliti, peningkatan pengetahuan WUS yang mendapat penyuluhan dengan metode demonstrasi lebih efektif dibanding WUS yang mendapat penyuluhan dengan metode diskusi disebabkan karena pada metode demonstrasi dipraktekkan cara melakukannya sehingga WUS dapat menggunakan indra pendengaran dan penglihatan lebih maksimal dibanding dengan metode diskusi yang hanya berfokus pada indra pendengaran.

\section{Efektifitas penyuluhan kesehatan tentang SADARI dengan metode diskusi kelompok dan metode demonstrasi terhadap Sikap WUS dalam Melakukan SADARI}

Hasil uji statistik diperoleh Sedangkan sikap dengan nilai $\mathrm{p}=0,330(\mathrm{p}>0,05)$, dengan demikian tidak ada pengaruh sikap WUS tentang SADARI. Dapat disimpulkan bahwa metode diskusi dan metode demonstrasi mempunyai sikap yang hampir setara tentang SADARI pada WUS. Selain itu juga karena dalam perlakuan demonstrasi dipandu oleh peneliti dan dibantu dari teman sehari-hari group nya yang sudah mempunyai ikatan lebih dalam sehingga akan lebih bebas untuk bertanya cara bersikap yang baik terhadap materi yang sudah disampaikan serta cenderung meniru sikap dari temannya.

Notoatmodjo mengatakan terbentuknya suatu perilaku baru, teruatama pada orang dewasa dimulai pada domain kognitif, dalam arti subjek tahu terlebih dahulu terhadap stimulus yang berupa materi atau objek diluarnya, menimbulkan respon batin dalam bentuk sikap, selanjutnya akan menimbulkan respon lebih jauh lagi berupa tindakan. Perilaku yang didasari oleh pengetahuan, kesadaran dan sikap positif akan bersifat langgeng. Ini terlihat pada hasil posttest tindakan kedua kelompok perlakuan. Selain itu, pada pelaksanaan penelitian antara pengambilan data pretest dan posttest hanya selang satu minggu. Padahal tindakan merupakan suatu aplikasi dari pengetahuan yang lebih maksimal apabila diukur dengan jarak yang lama.(Notoatmodjo, 2014)

Tindakan dipengaruhi oleh pengetahuan dan sikap. Tindakan yang dilakukan oleh WUS yang mendapat penyuluhan dengan metode diskusi berbeda dengan yang mendapat penyuluhan dengan metode demostrasi Perbedaan tersebut disebabkan karena pada metode demonstrasi, WUS dapat melihat langsung cara melakukan SADARI sehingga peningkatan pengetahuan dan sikap lebih tinggi.
Menurut peneliti, tidak ada pengaruh sikap WUS baik yang mendapat penyuluhan baik dengan metode demonstrasi maupun metode diskusi disebabkan karena sikap WUS merupakan reaksi atau respon yang masih tertutup terhadap suatu objek atau stimulus.

\section{Efektifitas penyuluhan kesehatan tentang SADARI dengan metode diskusi kelompok dan metode demonstrasi terhadap tindakan WUS dalam melakukan SADARI}

Hasil uji statistik diperoleh Untuk tindakan dengan nilai $\mathrm{p}=0,011(\mathrm{p}<0,05)$, dengan demikian ada pengaruh tindakan WUS tentang SADARI. Dapat disimpulkan bahwa metode demonstrasi lebih efektif dari pada metode diskusi kelompok dalam meningkatkan tindakan. Hal ini sesuai dengan hasil penelitian Nurisyah Safitri (2017) dalam penelitiannya juga menyimpulkan bahwa pendidikan kesehatan melalui metode demonstrasi tentang ketrampilan praktik SADARI berpengaruh terhadap ketrampilan praktik SADARI.(Safitri, 2017)

Tindakan dipengaruhi oleh pengetahuan dan sikap. Tindakan yang dilakukan oleh WUS yang mendapat penyuluhan dengan metode diskusi berbeda dengan yang mendapat penyuluhan dengan metode demostrasi Perbedaan tersebut disebabkan karena pada metode demonstrasi, WUS dapat melihat langsung cara melakukan SADARI sehingga peningkatan pengetahuan dan sikap lebih tinggi.

Menurut peneliti, peningkatan tindakan WUS yang mendapat penyuluhan dengan metode demonstrasi lebih efektif dibanding WUS yang mendapat penyuluhan dengan metode diskusi disebabkan karena pada metode demonstrasi dipraktekkan cara melakukannya sehingga WUS dapat menggunakan indra pendengaran dan penglihatan lebih maksimal dibanding dengan metode diskusi yang hanya berfokus pada indra pendengaran.

Pengetahuan, sikap dan tindakan tentang SADARI ini sangat perlu untuk ditingkatkan agar WUS mampu mencegah kanker payudara. Dengan adanya penyuluhan yang dilakukan oleh peneliti ini diharapkan agar WUS yang telah mendapat informasi tentang SADARI mampu untuk membagikan ilmu yang didapat kepada WUS lainnya

http://jurnalilmiah.stikescitradelima.ac.id/index.php/JI Vol.3,No.2, Januari 2020 


\section{SIMPULAN}

Berdasarkan penelitian dan pembahasan, maka dapat diambil kesimpulan sebagai berikut:

1. Karakteristik Wanita Usia Subur dalam melakukan SADARI di Desa Ambulu Kecamatan Wringin Kabupaten Bondowoso adalah usia responden dari kelompok diskusi paling banyak berusia $>30$ tahun sebesar $64,3 \%$ dan dari kelompok demonstrasi paling banyak berusia 20-30 tahun sebesar 52,4\%. Pendidikan pada kelompok diskusi paling banyak berpendidikan SD/SMP sederajat sebesar 69,0\% dan dari kelompok demonstrasi paling banyak berpendidikan SD/SMP sederajat sebesar 71,4\%. Pekerjaan responden dari kelompok diskusi paling banyak wiraswasta sebesar 55,7 \% dan dari kelompok demonstrasi pekerjaan paling banyak wiraswasta sebesar 64,3\%. Jumlah anak responden dari kelompok diskusi paling banyak 3 - 5 anak sebesar 85,7 \% dan dari kelompok demonstrasi jumlah anak paling banyak $3-5$ anak sebesar 76,2 $\%$.

2. Tingkat pengetahuan responden pada metode diskusi kelompok sebelum dilaksanakan penyuluhan kesehatan tentang SADARI paling banyak berkategori cukup sebesar 42,9\%. Sesudah dilaksanakan penyuluhan kesehatan tentang SADARI didapatkan hasil tingkat pengetahuan responden paling banyak berkategori baik sebesar $76,2 \%$.

3. Sikap responden pada metode diskusi kelompok sebelum dilaksanakan penyuluhan kesehatan tentang SADARI paling banyak berkategori positif sebesar $69,0 \%$. Sesudah dilaksanakan penyuluhan kesehatan tentang SADARI didapatkan peningkatan hasil sikap responden yaitu semuanya berada dikategori positif sebesar 100,0\%.

4. Tindakan responden pada metode diskusi kelompok sebelum dilaksanakan penyuluhan kesehatan tentang SADARI berkategori tidak terampil maupun terampil sebesar 50,0\%. Sesudah dilaksanakan penyuluhan kesehatan tentang SADARI didapatkan peningkatan hasil tindakan responden dikategori terampil sebesar $71,4 \%$.

5. Tingkat pengetahuan responden pada metode demonstrasi sebelum dilaksanakan penyuluhan kesehatan tentang SADARI paling banyak berkategori cukup sebesar 57,1\%. Sesudah dilaksanakan penyuluhan kesehatan tentang SADARI didapatkan hasil tingkat pengetahuan responden paling banyak berkategori baik sebesar $90,5 \%$.

6. Sikap responden pada metode demonstrasi sebelum dilaksanakan penyuluhan kesehatan tentang SADARI paling banyak berkategori positif sebesar $81,0 \%$. Sesudah dilaksanakan penyuluhan kesehatan tentang SADARI didapatkan peningkatan hasil sikap responden paling banyak berkategori positif sebesar $97,6 \%$.

7. Tindakan responden pada metode demonstrasi sebelum dilaksanakan penyuluhan kesehatan tentang SADARI berkategori tidak terampil sebesar $54,8 \%$. Sesudah dilaksanakan penyuluhan kesehatan tentang SADARI didapatkan peningkatan hasil tindakan responden berkategori terampil menjadi sebesar $83,3 \%$.

\section{DAFTAR PUSTAKA}

Aeni, N. (2018). Pengaruh Pendidikan Kesehatan Dengan Media Video Dan Metode Demonstrasi Terhadap Pengetahuan SADARI. Jurnal Care, Vol.6(No.2).

Azwar, S. (2008). Sikap manusia: Teori dan pengukurannya (Edisi 4). Yogyakarta: Pustaka Pelajar.

Damayanti, R. (2017). Pengaruh Pelaksanaan Pemeriksaan Payudara Sendiri (SADARI) Terhadap Pengetahuan dan Kemampuan Siswi Dalam Upaya Deteksi Dini kanker Payudara di SMP Neg.1 Sibulue Kab.Bone. Fakultas Keperawatan Universitas Hasanuddin.

Diniyati, I. (2012). Pengaruh Penyuluhan Kesehatan Tentang SADARI (Pemeriksaan Payudara Sendiri) Terhadap Pengetahuan Mahasiswi Keperawatan UIN Alauddin, Makasar. Fakultas Keperawatan Universitas Islam Negeri Alauddin Makasar.

Gusti, D. (2018). Pengaruh Promosi Kesehatan Memakai Metode Penyuluhan Dengan Teknik Demonstrasi Terhadap Pengetahuan Dan Sikap Siswi Tentang Pemeriksaan Payudara Sendiri

http://jurnalilmiah.stikescitradelima.ac.id/index.php/JI Vol.3,No.2, Januari 2020 
Di SMKN 2 Kec. Guguak Kab.Lima Puluh Kota. Jurnal Menara Ilmu, Vol.VII(No.8).

Hidayati, A. (2017). Pengaruh Pendidikan Kesehatan Melalui Metode Ceramah Dan Demonstrasi Dalam Meningkatkan Pengetahuan Tentang Kanker Payudara Dan Ketrampilan Praktik Sadari. Jurnal Kebidanan Unimus.

Kesehatan, D. (2018). Profil Dinas Kesehatan Kabupaten Bondowoso tahun 2018. Bondowoso.

Kholid, A. (2014). Promosi Kesehatan Dengan Pendekatan Teori Perilaku, Media, Dan Aplikasinya. Jakarta: Rajawali Pers.

Kholisotin. (2017). Efektifitas Paket Edukasi Preeklampsia Terhadap Pengetahuan, Sikap, Dan Keterampilan Ibu Hamil Yang Beresiko Mengalami Preeklampsia Di Kabupaten Situbondo. Universitas Muhammadiyah Jakarta.

Lestari, D. P. (2016). Pengaruh Penyuluhan Kesehatan Terhadap Pengetahuan, Sikap Dan Praktik Periksa Payudara Sendiri (Sadari) Santri Putri Pondok Pesantren Dawar Kabupaten Boyolali. Jurnal Kesehatan Masyarakat, Vol.4(No.2).

Marhaeni, G. A. (2017). The Breast Self-Examination (BSE) Behaviour among Balinese Women of Reproductive Age. International Journal of Science and Research (IJSR), Vol.6(No.10), 1818.

Mubarak, W. I. (2011). Promosi Kesehatan Untuk Kebidanan. Jakarta: Salemba Medika.

Notoatmodjo, S. (2014). Promosi Kesehatan dan Prilaku Kesehatan. Jakarta: Penerbit Rineka Cipta.

Nurfadilah, Puput, Puji Astuti, W. H. S. (2016). Pengaruh Tehnik Relaksasi Hand Massage Terhadap Nyeri Pada Pasien Payudara Di yayasan Kanker Indonesia Surabaya. Jurnal Ilmiah Kesehatan, Vol.9(No.2).

Nursalam. (2017). Metodologi Penelitian Ilmu Keperawatan. Jakarta: Salemba Medika.

Rahmatika, A. P. (2018). Perbedaan Penyuluhan Metode Ceramah Dan Diskusi Terhadap
Keterampilan Pemeriksaan Payudara Sendiri (Sadari) Pada Siswi Kelas Xi SMA N 1 Sewon. Fakultas Kedokteran Universitas Sebelas Maret Surakarta.

RI, K. K. (2016). InfoDATIN Pusat Data dan Informasi Kementerian Kesehatan RI. Retrieved from http://www.depkes.go.id/resources/download/p usdatin/infodatin/InfoDatinBulanPeduli20Kank erPayudara2016.pdf

Safitri, N. (2017). Perbedaan Metode Demonstrasi Terhadap Pemeriksaan Sadari Pada Siswi Kelas Xi Di SMA Muhammadiyah 1 Metro. Jurnal Kesehatan "Akbid Wira Buana, Vol.1(No.1).

Wawan, A \& Dewi, M. (2011). Buku Teori dan Pengukuran Pengetahuan Sikap dan Perilaku Manusia. Yogyakarta: Nuha Medika.

Yulinda, A. (2018). Efektivitas Penyuluhan Metode Ceramah Dan Audiovisual Dalam Meningkatkan Pengetahuan Dan Sikap Tentang Sadari Di Smkn 5 Surabaya. Jurnal Promkes, Vol.6(No.2), 126. 